\title{
The Struggle for a South African Film Audience
}

\author{
By Martin P. Botha \\ Spring 2004 Issue of KINEMA
}

IN THIS ARTICLE, the author aims to discuss the historical process which led to the fragmented nature of film audiences in South Africa presently. He examines the current status of film audiences and stresses the importance of audience development as an important option for the commercial growth of South African film industry.

\section{Background and Context}

The years 1959 to 1980 had been characterised by an artistic revival in filmmaking throughout the world, ranging from exciting political films in Africa and Latin America to examples of great art cinema in Europe and Asia. National cinemas ${ }^{(1)}$ emerged in Australia, West Germany, Iceland and New Zealand. In 1977 Iceland, for example, was nearly invisible on the map of world cinema. Few films were made there, but since the establishment of a national film commission similar to our NFVF (National Film and Video Foundation) an independent cinema emerged. Following the establishment of the New Zealand Film Commission in 197819 features were made over a period of five years, almost double the number for the previous eighty years.Unfortunately, due to moral and political censorship, a severe lack of audience development and inadequate film distribution, South Africans and thus local filmmakers were not exposed to these remarkable developments in world cinema. We made hundreds of Afrikaans soapies instead during this time, while the world, including several African countries, explored the artistic, social and political possibilities of the medium to the fullest!

Books by Botha and Van Aswegen (1992), Blignaut and Botha (1992), Botha and Dethier (1997) and Tomaselli (1988) documented developments in South African cinema in detail. A critical overview of the fragmentation of the South African film industry and of audiences in particular was presented in Schelfhout and Verstraeten's publication De rol van de media in de multiculturele samenleving (1998) and will only be briefly repeated here for the purpose of my discussion.

\subsection{Afrikaans language films}

Since 1956 and the introduction of a regulated subsidy system, the Nationalist government and big business collaborated to manipulate local filmmaking. Ideology and capital came together to create a national cinema that would reflect South Africa during the Verwoerdian regime of the 1960s. However, it was initially a cinema for whites only, and predominantly Afrikaans (Botha \& Van Aswegen 1992).

Of the 60 films made between 1956 and 1962, 43 were in Afrikaans. Four were bilingual and the remaining 13 were English. This subsidy system only rewarded box-office success. Once a film had earned a specific amount of money at the box-office, did it qualified for the subsidy, which paid back a percentage of costs. This percentage was initially higher for Afrikaans films than for English productions. It was therefore evident that the Verwoerdian government realised the potential influence this Afrikaner-dominated industry would have on the growth and spread of the Afrikaans language.

Since 1962, Afrikaner capital became a significant factor in the film industry when the insurance company SANLAM acquired a major interest in Sterfilms, a distribution company with the explicit intention to provide cinema predominantly for Afrikaner patrons. By 1969, Satbel (the Suid-Afrikaanse Teaterbelange Beperk) was formed, and the financing, production and distribution of films in South Africa were now virtually in the hands of one large company (except for a few cinemas owned by CIC-Warner) (see Shepperson \& Tomaselli 2002).

The white Afrikaans audience for the local cinema was relatively large and very stable, guaranteeing nearly every Afrikaans film a long enough run to break even as long as it provided light entertainment, basically escapism, and dealt in an idealist way with Afrikaner reality and beliefs (Botha \& Van Aswegen 1992). It meant that Afrikaners wanted their ideals visualised in these films. This idealistic conservatism was characterised by an attachment to the past, to ideals of linguistic and racial purity and to religious and moral norms (Botha \& Van Aswegen 1992). 
Sadly, severe moral censorship in the 1960s and 1970s prevented South Africans from viewing the international landmarks such as Fellini's Satyricon, Bertolucci's Last Tango in Paris and 1900, Pontecorvo's The Battle of Algiers and many other films, which at that critical stage would have challenged our conceptions of sexuality, politics, race and aesthetics.

Most Afrikaans films ignored the socio-political turmoil of the period, as well as the realities experienced by black South Africans. Botha and Van Aswegen (1992) stated that most Afrikaans films communicated by means of obsolete symbols that had little multicultural communication value. They painted a one-sided and stereotypical portrait of the Afrikaner, leading to a misconception about who and what the Afrikaner was. Furthermore, the negative portrayal of blacks as a servant class in these films is a visual symbol of the deep-seated apartheid ideology.

Attempts by directors to challenge the stereotypes of Afrikaners met with box office disaster. A very appropriate case study on The Guest, one of the most acclaimed local films, is provided in Keyan Tomaselli's book The Cinema of Apartheid (1988) By portraying one of the icons of Afrikaans poetry, Eugene Marais, as a drug addict, director Ross Devenish struggled to find an audience for his film.

\subsection{A black film industry by whites}

An attempt by the South African authorities to create a black film industry under apartheid during the 1970s resulted in the making of a large number of shoddy films in ethnic languages that were screened in churches, schools and community and beer halls. It was contrary to government policy to allow black cinemas in the urban white areas, as this would concede the citizenship of urban blacks. The urbanization of blacks was portrayed in these films as uniformly negative and homeland life as more fitting.

At this stage, black and white audiences were treated differently. South African audiences were separated each with its own set of rules and operations, films and cinemas. Any film that managed to be made which in any way reflected the South African society in turmoil, was banned by the state, or received no distribution whatsoever, and thus did not qualify for any film subsidy. A true national film industry did therefore not emerged through the Afrikaans and made-for-blacks films.

In sharp contrast to these movies Devenish portrayed the realities of South African black lives in a neo-realist approach in the award-winning Marigolds in August. Again, local audiences fed on Afrikaans soapies, stayed away and the director left South Africa to work in the United Kingdom.

In the early 1980s, film attendance dropped to its lowest level as a result of the popularity of television and a scarcity of good films. David Bensusan's film, My Country my Hat (1983) was one of the few creative films that made an innovative contribution to sociopolitical satire (Louw \& Botha 1993:166).

\subsection{An alternative South African cinema}

Since the late 1970s and the early 1980s a group of film and video producers and directors who were not affiliated to the established film companies in the mainstream film industry, made films and videos about the socio-political realities of the majority of South Africans (Botha \& Van Aswegen 1992; Blignaut \& Botha 1992). Some of these films were shown at local film festivals such as the Durban and Cape Town International Film Festivals, and from 1987 until 1994, the Weekly Mail Film Festival. Other venues included universities, church halls, trade union offices and the private homes of interested parties. Many of the films experienced censorship problems during the State of Emergency during the 1980s, and some were banned.

The films had small budgets and were either financed by the producers themselves, by progressive organisations (such as the International Defence and Aid Fund for South Africa for a united, democratic, non-racial South Africa) and overseas television stations. These films were chiefly the product of two groups that emerged jointly: a group of white university students opposed to apartheid, and black workers who yearned for a film or video form using indigenous imagery that would portray their reality in South Africa that would give them a voice and space in local films. Together with numerous documentaries, community videos and full-length films such as Mapantsula, short films and even animation work marked the beginning of a new, critical South African cinema.

Initially this new cinema was based on audio-visual material that reflected the realities of the black majority of South Africa in their aspirations and struggle for a democratic society, but since the beginning of the 1990s 
other marginalised voices were added to these documentaries and short films, for example those of women, gays and lesbians, and even the homeless. It is from these films and videos that the symbols and iconography of a national South African film industry can be drawn, rather than from the diversions produced by the Afrikaans cinema of the 1960s and 1970s, or the made-for-blacks cinema of the 1970s. Most of the new critical local films, features or short films can be described as progressive film texts in the sense that the majority of them are consciously critical of racism, sexism or oppression. They dealt with the lives and struggle of the people in a developing country and were mostly allied with the liberation movements for a non-racial, non-sexist South Africa.

Some of these films (short, features and documentaries) also dealt with events which were conveniently left out in official South African history books or in a contemporary context in actuality programmes on national television under control of the Nationalist regime. Therefore, they became guardians of popular memory within the socio-political process in South Africa.

According to Tomaselli (1988:226), 1986/1987 can be regarded as the turning point in the South African film industry. Only then did several feature films begin to critically examine the South African milieu, apartheid and colonial history. Tomaselli calls this the new wave in the South African film industry. Martin Botha and Adri van Aswegen labelled it an alternative film revival, a cinema that gave a voice to those who were previously marginalised by apartheid (Botha \& Van Aswegen 1992).

The films touched on issues of black-white conflict and friendship (Jock of the Bushveld), the poor treatment of black farm workers by certain farmers (A Place of Weeping), the effects of war on whites ('n Wêreld sonder Grense), terrorism (City of Blood) and the trauma of racial conflict (Saturday Night at the Palace) (Louw \& Botha 1993:167).

Approximately 944 features were made during the 1980s, as well as nearly 998 documentaries and several hundred short films and videos (Blignaut \& Botha 1992). Although most of the features were of mediocre value, at least 20 to 30 remarkable indigenous local feature films were made. They included Mapantsula, a vivid portrayal of the State of Emergency in the late eighties; On the Wire, about the psychological scars left by the war in Namibia and Angola; The Road to Mecca, a film on the life of artist Helen Martins; Andrew Worsdale's Shotdown, a political satire; the evocative Afrikaans dramas with strong female characters - Fiela se Kind, Die Storie van Klara Viljee and Paljas; Jobman, a strong anti-apartheid drama set in the years after Sharpeville; and Manie van Rensburg's masterful portrayal of Afrikaner nationalism during the 1940s in The Fourth Reich.

Unfortunately many of these films remain unseen by the majority of South Africans. Some were severely censored like The Stick and Shotdown. Jobman and Shotdown were never released commercially. In fact, by the end of the 1980s and early 1990s it was easier to view these films in London, Amsterdam and Paris, than in South Africa.

One should also note that cinemas were only desegregated in South Africa by 1985. And SABC channels during the 1980s also led to very fragmented audiences across race and language.

Despite the lack of audience support, directors like Jans Rautenbach, Manie van Rensburg, Ross Devenish, Darrell Roodt and Andrew Worsdale are evidence that there is indeed great talent in the local film industry. Van Rensburg's The Native Who Caused all the Trouble and The Fourth Reich are films that built on the foundation of the post-1987 new wave (Botha \& Dethier 1997). The failure of The Fourth Reich at the South African box office, however, was a shock for the local film industry. This impressive and entertaining saga of Afrikaner nationalism during the early 1940s cost some R16 million, raised mostly through the tax break scheme of the 1980s. The film opened with 20 prints, highly favourable reviews and a saturated media. Van Rensburg won the best director award at the South African Awards ceremony, but all these favourable variables couldn't result in box office victory for one of our best film directors.

By the beginning of the 1990s we had a fragmented film industry with fragmented audiences.

1.4 Attempts to create a national film commission The year 1994 could be regarded as a landmark for the South African film industry due to the historic democratic elections and the birth of a post-apartheid society. A comprehensive study by the research institution, the Human Sciences Research Council (HSRC), 
into the restructuring of the entire South African film industry was completed and forwarded to the Department of Arts, Culture, Science and Technology (Botha et al. 1994). The report of 400 pages received widespread praise throughout the local film and television industry, especially by members of the Film and Television Federation (FTF)(Botha 1997b). The HSRC research team recommended that state aid to the local film industry should be administered by a statutory body referred to as the South African Film and Video Foundation (SAFVF). Commercial viability should not be the sole criterion for government support of locally made films. All types of films, including short films, should benefit, and a developmental fund should be used to support first-time filmmakers from previously marginalised communities.

The underlying assumption should be that a diversity of film types would make the film industry as a whole more healthy, with France as an excellent example. A film industry, which is focused exclusively on maximizing profit, would inevitable become shallow and artless. In general the dilemma of the local film industry could be attributed to the fact that film was seldom regarded in South Africa as a cultural industry. Although film can be regarded as a commercial product, it should also be seen as a product of culture, such as indigenous literature, theatre, the plastic arts and music.

A sustained level of government/private sector aid to the post-apartheid film industry would be necessary to ensure the continued existence of South African cinema. Even the highly developed "First World" film industries outside the United States such as Canada, Australia, New Zealand, France and the Scandinavian countries cannot survive without ongoing support from the state. This does not mean that financial support to the local film industry is sunk into a "bottomless hole". As in the case of Burkina Faso, one of the poorest countries in the world, but boasting a vibrant film culture, the South African public would reap the benefits of a healthy film industry on the levels of development, cultural reconstruction, progress and eventually prosperity for the country as a whole.

It was thus recommended in the HSRC study (Botha et al. 1994) that the proposed Film and Video Foundation should support all aspects of the film industry. The audio-visual industry forms an organic whole where each of the parts contributes equally to the overall success of this industry. Production, distribution, exhibition, training, archives management, research and information, visual literacy programmes and the promotion and marketing of locally produced films and videos are essential elements of the relationship between film practitioners and the public.

The South African Minister of the Department of Arts, Culture, Science and Technology, Dr Ben Ngubane, formalized an Arts and Culture Task Group (ACTAG), in August/September 1994, to counsel him on the formulation of policy for the newly established government. The aim of this group was to assist the Minister to realise relevant objectives as set out in the Reconstruction and Development Programme, namely: to affirm and promote the rich and diverse expression of South African culture, so that all citizens are guaranteed the right to practise their culture, language, beliefs and customs, as well as enjoying freedom of expression and creativity. Obviously, the film industry has a crucial role to play in the forging of social cohesion and the process of democratization and development in South Africa.

In November of 1995, four months after the final ACTAG document was published, Dr Ngubane appointed a Reference Group to write up the Film Development Strategy document. This Reference Group comprised fourteen disparate members: individuals from the film industry; academics such as Keyan Tomaselli; the head of the HSRC research study into the film industry, Martin Botha, and the film consultant to the Minister (and Chairperson). The Reference Group met over a period of four weeks to discuss the drafting of the document, using the ACTAG document as the foundation for this paper. The first draft of the Film Development Strategy document appeared at the beginning of 1996, and a revised version was published later in the year.

The writers proposed that the South African film and video industry be administered by a Statutory Body, known as the South African Film and Video Foundation (SAFVF). The Reference Group felt that it was important to include "video" in the name, as it is then obvious that the Foundation embodies that area.

One of the long-term aims of the proposed Foundation is to facilitate the placement of the South African film industry on a sound commercial footing and enable it to become internationally competitive. This in turn will promote South Africa as a tourist attraction, and as a location for foreign film productions, and 


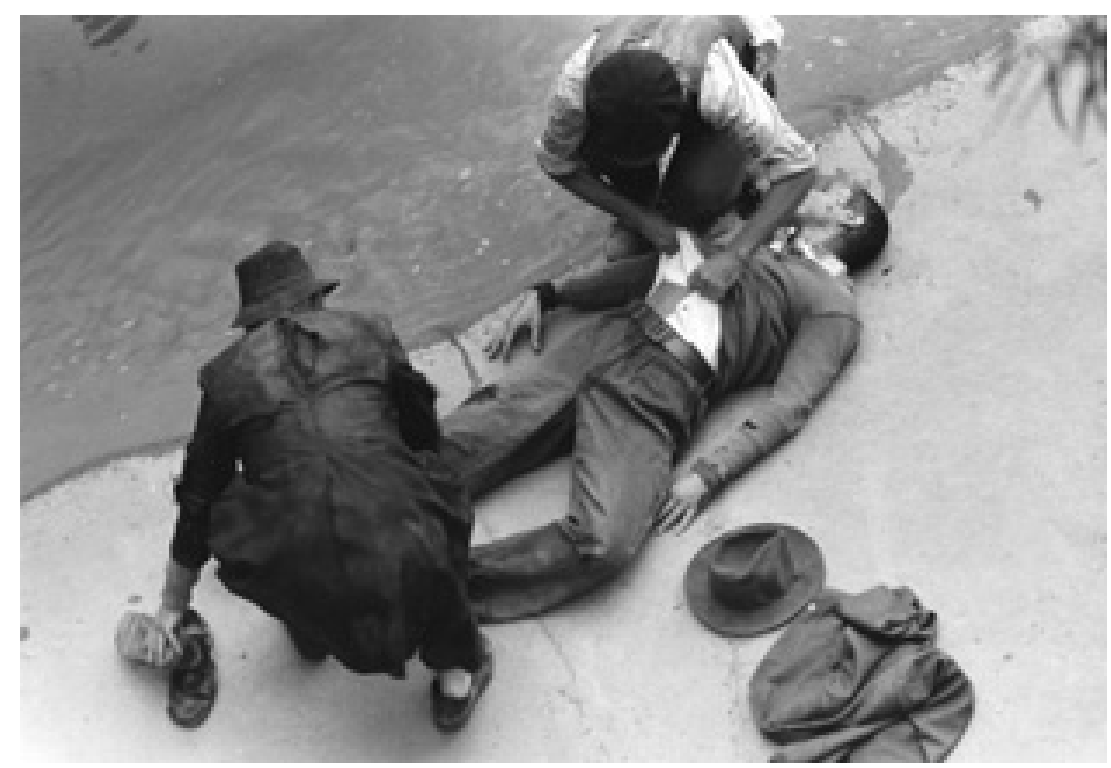

Figure 1: Jobman (Dir. Darrell Roodt, 1990)

television and advertising commercials. It will also enable South African audiences to see their own stories and interpretations of experience reflected on local screens.

In March 1995, the old South African film subsidy system, which was based on box office returns, ceased to exist, and an interim film fund became in operation. Ten million rands were annually distributed among various projects, which included funding for short filmmaking. In 1998, for example, R110,000 ${ }^{(2)}$ was allocated to the development of short films and R1,010,000 for the actual production of short films. During 1999 the proposed National Film and Video Foundation was established to support the local film industry, including short filmmaking.

\subsection{Objectives and strategies of the NFVF}

The inaugural council of the NFVF translated the objectives of the NFVF Act into specific strategies. These strategies are as follows:

- Establish effective relationships with the Minister of Arts, Culture, Science and Technology and other Government departments and regulatory bodies to influence policy and access funds;

- Establish effective relationships with the National Lottery, private investors and international donors in order to access funds for the industry;

- Build effective relationships with the film and video industry;

- Initiate and support the development of diverse and effective education and training for the film and video industry - the foundation is mandated to conduct a feasibility study for the establishment of the South African National Film School;

- To initiate, conduct and consolidate relevant research and communicate the findings to the industry;

- To ensure domestic production and content growth;

- To ensure the growth and sustainability of existing and new audience development initiatives;

- To develop and implement effective domestic and international marketing and distribution strategies;

- To create awareness of existing incentives in the film industry and actively promote additional incentives for the industry, and to develop a mutually beneficial environment to attract international film productions; 
- To research, design and implement innovative fund disbursement approaches;

- To promote a climate within which sustainable small, medium and micro enterprise (SMME) development can take place;

- To redress past imbalances in the industry by actively identifying and addressing these problems through all NFVF activities; . To establish conditions for the efficient and effective running of the Council of the NFVF; and

- To establish an efficient and effective NFVF office that is capable of achieving the Council's objectives.

Since the collapse of apartheid it became important for South Africa to establish partnerships with other film industries. One such partnership could be with the European Union (EU) and its member states. Set within the context of the signed trade cooperation and development agreement between South Africa and the European Union, the South African Department of Arts, Culture, Science and Technology together with the NFVF and the delegation of the European Union in South Africa hosted a film symposium during November 2000 in Johannesburg. The participants of the symposium were drawn from the ranks of chief executive officers of the EU member states' film commissions, as well as significant players in the South African film and television industry.

The objectives of the symposium were to develop and sustain robust co-productions between the EU member states and the South African film industry, to create varied product for the film and television markets of the territories concerned, as well as to develop a framework that will ensure the strengthening of small and medium size enterprises initiatives in the film sector. The aim was also finally to work towards the establishment of a financial framework for financing of co-productions between the European Union and South Africa.

The Department of Arts, Culture, Science and Technology also commissioned a study, which provided an overview of the current status quo of the South African film industry. The PricewaterhouseCoopers report (Nel 2000) concentrated on the core activities of film and television production across the film industry value chain. The study highlighted the areas of opportunity and growth in the South African film industry.

The results and recommendations were presented at the symposium. It was estimated that less than 15 productions companies produce more than $90 \%$ of all feature film and television productions in South Africa, although there are currently more than 150 registered producers in the country. The industry was also traditionally highly dependent on the commissioning activities of the National Broadcaster for the majority of production work. According to the latest research, the revenue generated from television production currently constitutes approximately $36 \%$ of the total annual film/television revenues. This trend is expected to continue for various reasons, including the fact that the television audience in South Africa is growing at approximately $13 \%$ per annum (based on the free-to-air audience growth).

The South African film industry generates close to R1,4 billion worth of production per annum, but the funding provided by government is currently a mere R10 million per annum, implying a funding ratio of 0,7 $\%$. It was clear from this finding in the report that much can be done to increase the government-funding ratio (the ratio between the size of the industry and the amount of funding made available to the industry) if the South African film industry funding is to be comparable with international benchmarks.

The most significant trends shaping the South African film industry currently are:

- The emergence of black film talent. Directors such as Zola Maseko (The Life and Times of Sara Baartman), Ntshavheni Wa Luruli (Chikin Biznis - The Whole Story), Akin Omotoso (God is African), Teboho Mahlatsi (Portrait of a Young Man Drowning), Dumisani Phakhati (Christmas with Granny) and Norman Maake (Home Sweet Home) have impressed local and international audiences with a number of documentaries, shorts and features over the past few years,

- The alignment and consolidation of the independent film production sector,

- Past and recent surges of media donor funding for the development of documentaries,

- International demand for South African conservation and wildlife productions, 
- Strong recent South African participation in international markets,

- The signing of a co-production treaty between the NFVF and Canada and memoranda of understanding with countries such as India and Sweden, as well as South African industry players such as M-Net and the Media, Advertising, Publishing, Printing and Packaging Sector Education and training Authority (MAPPP-SETA)

- The realization and in some cases active steps towards the use of digital production formats and its applications thereof in an African setting,

- The decrease in video hire activity,

- The increase in video sell-through, and, lastly,

- A newly re-regulated broadcasting industry that still needs well defined monitoring mechanisms to drive measurements regarding local content quotas from a production point of view.

Feature film production currently exists on two levels: Co-productions and locally made movies. The most lucrative is the facilitation of international and foreign films that find South Africa to be a useful location in terms of flexible and original sites, and the favourable exchange rate. Since 1995, there are on average five features produced every year, with the most active company being the British company, Peakviewing. Their 12 million dollar production, Glory Glory, was shot near Johannesburg. An epic Western, it follows a renegade gang of women led by Hannah (Chantelle Stander) who embark on a campaign of terror in Texas as a way of wreaking a kind of vengeance on a society they feel has failed to protect them from the ravages and degradation of the Civil War. Peakviewing has had a consistent production output since 1993. It includes family films such as The Fairy King of Ar, The Last Leprechaun, The Little Unicorn and Merlin: The Return. Since 1999 it made another three films here: Africa! with Elizabeth Berkley and Patrick Bergin, about a model who is forced to survive in Africa, as well as Pets! with Christopher Atkins and Dazzle.

Another foreign-financed film that finished shooting, was $\operatorname{Dr}$ Lucille, one of the first films to be made under the South African/Canadian co-production treaty. Budgeted at R20 million it tells the true story of Canadian Dr Lucille Teasdale, who with her husband, pediatrician Piero Corti, started a dispensary and for more than two decades dedicated their lives to caring for the sick and wounded in the civil war in Uganda. Another co-production with Canada is Proteus, with financing from the NFVF, Telefilm Canada and several Canadian broadcasters. Directed by John Greyson and Jack Lewis, it is produced by Steven Markovitz and Platon Trakoshis of Big World Cinema. Based on a true story, it is a period film that raises issues still of enormous relevance today. Historian and filmmaker Jack Lewis was fascinated by a court record in the Cape Archives, dated 18 August 1735, giving judgement in the case of two Robben Island prisoners. Dutch sailor Rijkhaart Jacobsz and Khoe convict Class Blank received extreme sentences for what the court called 'the abominable and unnatural crime of Sodomy'. Proteus was one of ten features, which were shot in and around Cape Town during the 2002. The film features five languages- English, Afrikaans, Dutch, Nama and Latin.

The only South African company to make a significant number of films in South Africa is the Durban-based Videovision, which was responsible for landmarks such as Cry the Beloved Country and Sarafina!.

Most locally produced films are less successful than co-productions. While revenue generated from coproductions has increased at a rate of $63 \%$ per annum from 1997 to 1999, revenue generated from $100 \%$ local production has shown little growth during the same period. In fact, the number of local films released annually in our cinemas has been declining from 1991 to 1999. South Africa has currently about 801 screens, dominated by Nu Metro and Ster Kinekor (612 combined) as the two biggest players and including a couple of independents (189). Indications are that this number should stabilize and that any significant increase up to 2004 is improbable. In real terms, only 16 locally produced films have generated more than R6 million at the South African box office during the past twenty years. Most of them were slapstick comedies, such as Mr. Bones, The Gods Must Be Crazy and Funny People.

During 1997 - 1999, when the DACST Interim Film Fund was in place, 1203 applications for grants were received, of which a total of 414 projects received allocations worth over R30 million (Nel 2000:21). The annual budget was R10,685 million, however there was recognition of the need for a more coherent and strict monitoring system. Such a system was put in place by the NFVF Council in 2000. 
The annual interim film fund project expenditure was as follows:

- 1997 - R 9835 million

- 1998 - R10 225 million

- 1999 - R10 563 million

During these first three years the majority of the funding allocated by the DACST Interim Film Fund went towards production $(41 \%)$, content creation $(22 \%)$ and training $(21 \%)$. With regard to the value chain activities, the following is evident of the projects initiated via the Fund (1997-1999):

- Content creation (R6 928 million) - Most of the funds (48\%) have been allocated to features, whilst the balance are mostly divided between television (23\%) and documentaries (21\%).

- Production and post-production (R13 507 million) - The major benefiting sub-sectors were documentaries (49\%) and features (29\%), with television a distant third.

- Training (R5 946 million) - A good balance was created between institutional training (54\%) and on-the-job or project-based training $(46 \%)$.

- Promotion (R3 312 million) - All the funds were utilised through promotion at international film markets and festivals.

When the NFVF took over the allocated funding by DACST a funding criteria document was drafted and made available to the film and video industry in 2000 for their input. Based on an extensive consultative process the funding criteria document was adopted by Council as policy and implemented. Funding is provided in four broad categories:

- Education and training

- Development

- Production

- Marketing and distribution

Individuals, companies and organizations may submit funding applications to the NFVF for grants or grant loans, but specific conditions are applicable in each funding category. For each of the categories an advisory panel with relevant expertise in that area has been constituted.

\section{The NFVF Indaba on the Film and Television Industries}

On Saturday 11 August 2001 the NFVF hosted an industry Indaba to present to the film and video industry research findings on matters such as film production, co-production and local content; finance, funding and taxation; marketing and distribution; as well as training and development. The way forward was also discussed with industry players and stakeholders.

The following findings from research input by the panels were an indication of the status of the film and video industry, and thus the challenges faced by the NFVF. The findings and recommendations are summarized for each field of research.

\section{Production:}

- Theatrical filmmaking is presently not an industry

- Television productions are inadequately funded and generally not of international standard

- The commercials production industry is highly successful

- The long format servicing industry has slowed down

- The commercials servicing industry is lucrative but driving prices through the roof.

It was recommended by the researchers that once the new ICASA local content regulations are announced, the NFVF has to host a separate conference to address matters concerning South African content. The NFVF has to drive a short film initiative and more investment should flow into audience development. Broadcaster partnerships for feature and short films have become crucial. A climate needs to be created for the growth of small independent production companies by increasing the number of productions commissioned from 
small production companies. The establishment of a regular cycle of commissioning of works by all the broadcasters, perhaps twice a year, could contribute to this climate. The NFVF must actively pursue coproduction treaties with African and other international film industries. It was noted that no reference has been made by the researchers to the important potential of new media.

\section{Finance, funding and taxation:}

- There is an emerging domestic and international interest in the South African film and television industry

- There is a visible growth in local and international co-productions

- The historical experience of film investment in South Africa still carries a negative impression

- Film financing facilities are still emerging

- Financial services industry, however, remains cautious about the film industry as a viable investment

- Broadcasters have not yet developed sophisticated finance and funding models

- Local content regulations and audience demand have given rise to increased demand for South African product

It was recommended that the NFVF should establish an advisory Panel in terms of the NFVF Act with the participation of the Departments of Trade and Industry and Finance, to investigate and make recommendations on funding and finance policy in respect of:

- Fair and generally accepted criteria for the allocation of NFVF funds

- The improvement of accountability mechanisms for usage of government funding

- The creation of distinct commercial and development funds

- The establishment of a full time finance and funding office within the NFVF

- A substantive audit of all income tax allowances and trade and industry incentives, as well as the National Lottery fund

- Investigating additional revenue sources such as withholding tax on royalties paid to foreign film distributors, box office levies and incentives for private contributions to a National Film Fund

- The liaison between the NFVF and SARS regarding the consistent application of section $24 \mathrm{~F}$ of the Income Tax Act, ${ }^{(3)}$ including: clarifying status and opportunities of section $24 \mathrm{~F}$, and proposing amendments where necessary, and the role of the NFVF in assisting Revenue practice through South African film certification

- The consolidation of general Department of trade and Industry subsidies and incentives through one NFVF office

- The liaison with the reserve Bank regarding criteria for forex approval in respect of export investment structures

- Consistency and co-ordination with best international practice regarding co-production treaties, memos of understanding between the NFVF and foreign film

- commissions/institutes, as well as an analysis of international models capable of local application

- Advise on strategy for marketing the film and video industry as a viable investment nationally and internationally

- Investigate alternative sources of government funding

- Liaison between the NFVF and ICASA on application of local content regulation, and lastly,

- The development of a national strategy for public funding and private finance models for the film and video industry.

Significantly, questions were raised at the Indaba about the possibility of the government creating additional tax incentives to boost the film industry. Examples cited of additional incentives included a payroll tax credited, which is used widely in other countries. Value Added Tax (VAT) is collected on cinema tickets and it was suggested that this revenue be reallocated to the film industry. It was also suggested, as years ago in the HSRC report by Botha et al. (1994), that South Africa consider implementing a withhold tax on foreign films screened here. Concern was raised among conference delegates about the practices of certain 
investment companies that are exploiting South African incentives to finance foreign films without any benefit to the local industry. The South African government, together with the NFVF, needs to move towards the development of consistent national policies in support of finance and funding of the film industry. An integral part of this is mobilizing additional resources to increase the size of the NFVF Film Fund so that it is able to meet the needs of the film and video industry.

\section{Marketing and distribution:}

- South African product distributors are insignificant in the global arena

- Many South African films experience no box office success

- Current international marketing strategies by South Africans are insufficient

- Local producers focus on making and not selling films

- Local films have difficult access to large markets

It was recommended that the NFVF provide an infrastructure for global marketing strategies, that incentives are created for local broadcasters to promote South African films, that new media is involved in marketing and distribution strategies and that training providers add new media to film training courses.

\section{Training and development:}

- Many training institutions in South Africa has done little to address past imbalances in the film industry

The NFVF has a clear mandate contained within the NFVF Act to explore the feasibility of establishing a National Film School.

From the industry input during and after the Indaba a NFVF Strategy for the South African film sector was drafted in 2002 and adopted by Council. The challenges faced by the NFVF are, however, enormous. The estimated size of the worldwide convergence market of entertainment and information and communications technologies is $\$ 386$ billion, which translates roughly into R3,8 Trillion. South Africa's entertainment industry accounts an insignificant share of 0,3 to 0,5 percent of this wealth. Vigorous competition with the rest of the players to increase their share of this lucrative market is but one challenge faced by the post-apartheid film industry and a statutory body such as the NFVF. Fortunately, the film sector has been redefined as part of a cultural, knowledge and information industry. The cultural industries in South Africa have been singled out as one of the sectors with the potential to contribute to higher growth rate and job creation. The NFVF will have to play its part to ensure this success. After the Indaba it received a $50 \%$ increase in its allocation in the 2001/2002 financial year, enabling it to start the year with R18 million in its coffers. In addition, the Minister of Arts, Culture, Science and Technology announced a further R35 million allocation for the production of short and feature length films over the next three years, which will also be managed by the NFVF. In the upcoming year, R27 million is available for the funding of projects in the film and television sector. It is still far from the budgets of international commissions such as the CNC in France, but a step in the right direction.

During the year 2002 R8 916,145 were invested in the production of 15 documentaries, one feature, five short films, one television series, one animation production and the post-production of one project. Fifteen training institutions and 12 student applicants for bursaries were supported. Distribution and marketing grants were provided to six institutions/organizations and a further 39 grants for development of documentaries, features and television series were made available. In total 96 projects were supported and the first signs of success are visible: International acclaimed films such as Promised Land and Zola Maseko's A Drink in the Passage were co-funded by the NFVF.

3. South African Audiences and Recent South African Cinema Despite the establishment of the NFVF and significant positive initiatives such as the Film Resource Unit to develop audiences for South African films, local filmmakers are still struggling, almost three decades after Ross Devenish's attempts, to find an audience for their work. The poor local performance of internationally acclaimed films such as $A$ Reasonable Man, Chikin Biznis - The Whole Story, and The Long Run leaves one of a feeling of déjà vu.

A film industry or in more ambitious terms, a national cinema, is ultimately dependent on the number of people who are willing to pay for it. Without a paying audience, whether it is cinema, television, video or new media exhibition, there can be no industry to speak of. With a total population of approximately 42 
million people South Africa has a tiny cinema-going audience measured at approximately 5 million persons with a rapidly growing television consuming public penetrating approximately $49 \%$ of the total number of South African households.

Several research reports and publications, from Tomaselli (1988) through Blignaut \& Botha (1992) to the report on marketing and distribution for the 2001 Indaba (NFVF 2001), provided a comprehensive overview of the historical and present factors, which shaped film audiences in South Africa. Some of the most important findings and recommendations are the following:

- When comparing South Africa to developed markets we utilise research and marketing methodologies based on so-called first world models and income groups. Herein lies part of the problem when it comes to the implementation of market development and growth strategies based on research methods not suited to the South African reality.

- Our film industry has been held to ransom for decades by the developed markets' funding and exhibition models, content and distribution strengths and world-wide dominance of the Hollywood studios. It has been estimated that Hollywood product dominates $92 \%$ of screen time in South African cinemas. Local filmmakers have to compete with films by independent American, British and Australian filmmakers, as well as "art-house" films from Europe, the Middle East and Asia for the remaining $8 \%$.

- One of the key problems within the local exhibition sector are the inaccessible film exhibition sites that are outside the reach of the majority of South Africans, the limited concentration of theatres in metropolitan areas and the general lack of culturally specific, community based film exhibition points and product.

- Audience attendance at South African cinemas is decreasing at an alarming rate to the extent that exhibitors have had to close down cinemas, especially in townships. Some independent cinemas in townships have been converted to churches. Various factors contributing to this decline, including the increase in the range of entertainment media, especially a wider range of television content, door price increases, unemployment, crime, and a lack of effective marketing strategies.

- Some theatric distributors such as UIP (United International Pictures) owned by international studios merely serve as a "courier service" between the international studios and the local exhibitors. They do not have a quota system for local content distribution and exhibition and the rationale that informs their decision to acquire and to exhibit or NOT to acquire and exhibit product is based on the commercial viability of the product. Criteria used to determine viability is sometimes out of touch with South African and African realities, especially if one studies the cultural role of cinema within African communities.

- The unfair competition and massive marketing budgets of Hollywood studio backed film releases reduce the chances of South African box-office success at the cinema level. The introduction of incentivised screen quotas for domestic and African film theatric releases thus becomes a necessary intervention. France is an important case study in this regard. · Through audience development programmes South African distributors and exhibitors can ultimately create a demand for local content on the screen, video hire, video sell thru, pay TV, free TV and public broadcasters, both locally and internationally. The screening of award-winning local short films such as The Sky in her eyes as part of a theatrical programme by Ster-Kinekor should be applauded.

- The Film Resource Unit (FRU) reaches audiences of at least 300 to 500 thousand per annum, free of charge. FRU plays a significant role in local film audience development.

- There is a need for aggressive marketing of South African films in people's home communities and the generation of local media enthusiasm around promotion of local product. Local film journalists and critics are to be encouraged to support local product.

- All provincial film commissions should include distribution, promotion and exhibition initiatives in their overall development strategies, encouraging South African film festivals and retrospectives country wide and internationally. It is critical that such festivals are marketed to the people to create a high level of awareness. A festival such as Apollo plays a significant part in this regard. 
- Government subsidies and lottery funds to increase mobile film units with screenings in community halls, churches and school halls, as well as opening cinemas in townships, should be considered.

- Some valuable recommendations are provided in the Indaba 2001 Report on Marketing and Distribution (NFVF 2001). A strong emphasis is placed on audience development.

\section{Conclusion}

I would like to emphasize the fact, that a national South African cinema of diversity should be encouraged on all levels. Film is not only for getting bums on seats, but ALSO a means of self-expression by voices, which were silent during the apartheid years. Those voices could belong to blacks, women, gays and lesbians, and others, who never had the opportunity to express themselves.

One could just look at three decades of African cinema to note the role played by film in the exploration of sociopolitical issues, popular memory, modes of communication and providing a space and a voice to those, who never had the power in their representation on film. In the face of globalization South African documentaries such as The Great Dance and Ochre and Water again remind us of the dangers of disappearing cultures and communities.

If making profit is the only determining factor for the advancement of cinema, we would never had the remarkable aesthetic, social, technological and social developments in international cinema during the past hundred years: The Soviet Montage Movement and German Expressionism of the 1920s, Italian neo-realism in the 1940s, the French New Wave of the sixties, the New German Cinema and the Australian New Wave of the 1970s, the $5^{\text {th }}$ Generation of Chinese filmmakers who took the world by storm in the 1980s and the Dogme Movement started in Denmark in the 1990s.

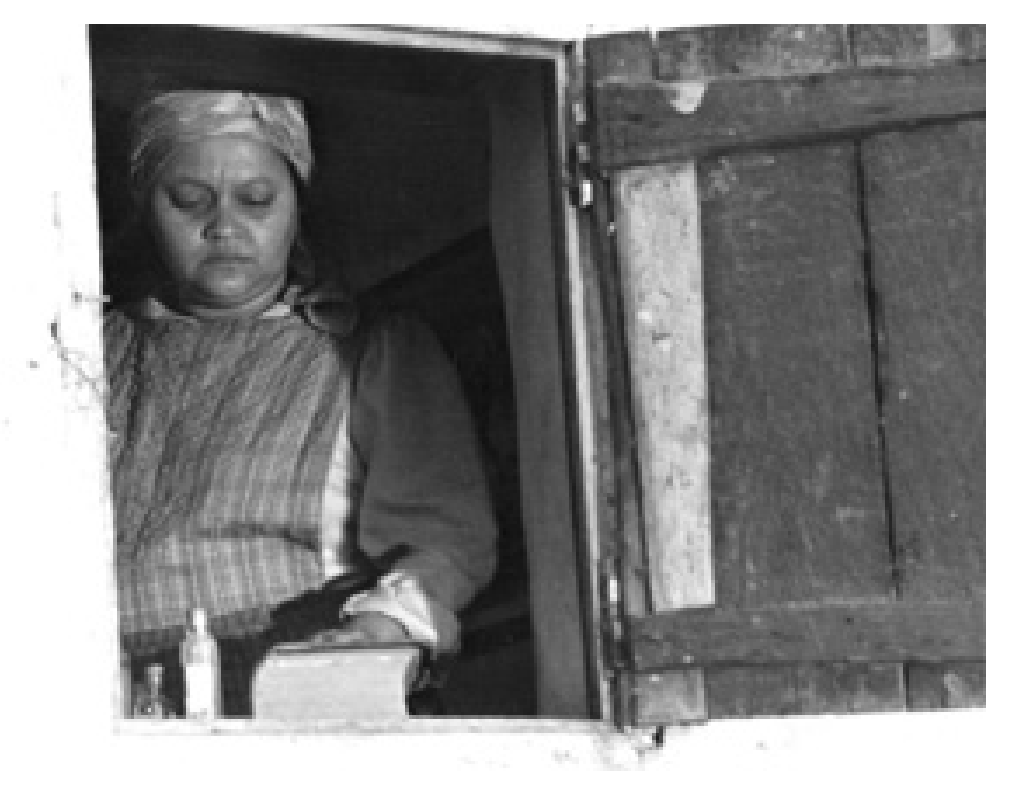

Figure 2: Fiela's Child (Dir. Katinka Heyns, 1988)

\section{Notes}

1. The concept "national cinema" is a complex one. Throughout history there has been a constant interaction between social organization and culture. By definition culture is a term which refers both to material production (artifacts) and to symbolic production (The aesthetic). In both instances, culture functions as the record and reflection of social history and the social process. Concepts of nation and national identity 
are also bound up in this socio-cultural functioning. Susan Hayward (1993) raises important issues regarding the concept of a nation and a national cinema.

2. At the 2004 exchange rate, one South African Rand is worth 0.15 USD. [Editor's note.]

3. Section $24 \mathrm{~F}$ of the Income Tax Act provides taxpayers with a deduction on taxable income on any amount invested by the taxpayer in the production, post-production or international marketing of a South African film. However, if an investment is made on the basis of credit or loans, or is otherwise not paid for in the relevant tax year of assessment, the taxpayer will only be allowed to claim a deduction to the extent that she/he is at risk in respect of future income derived from the exploitation of the film.

\section{References}

\section{Bibliography}

Blignaut, J. \& Botha, MP. (eds.) Movies Moguls Mavericks: South African cinema 1979-1991. Cape Town: Showdata, 1992.

Botha, MP. An introduction to South African Cinema. Unpublished report, 1996.

Botha, MP. "South Africa". In International film guide, edited by P Cowie. London: Hamlyn, 1997 a.

Botha, MP. "My involvement in the process which led to the White Paper on South African cinema." South African Theatre Journal 11 (1\&2):269-285, 1997b.

Botha, MP. "Overview of South African cinema." In De role van de media in de multiculturele samenleving, edited by E Schelfhout \& H Verstraeten. Brussels: VUBPress, 1998.

Botha, MP. "South Africa." In International film guide, edited by P. Cowie. London: Faber and Faber, 2000 .

Botha, M.P., Mare, L., Langa, Z., Netshitomboni, R., Ngoasheng, K., Potgieter, J. \& Greyling, M. Proposals for the restructuring of the South African film industry. Pretoria: Human Sciences Research Council, 1994.

Botha, MP. \& Dethier, H. Kronieken van Zuid-Afrika: De films van Manie van Rensburg. Brussel: VUB Press, 1997.

Botha, MP. \& Van Aswegen, A. Images of South Africa: The rise of the alternative film. Pretoria: Human Sciences Research Council, 1992.

Fourie, PJ. Zuid-Afrika, in Nederlandstalige en Afrikaanstalige media, 2de internationale colloquium, Nederlands in de wereld, onder redaksie van N van Zutphen \& J Nootens. Brussel: Vlaamse Raad: 279-341, 1994.

Hayward, S. French national cinema. London: Routledge, 1993.

Louw, PE \& Botha, JR. Film: the captivating power of fleeting images, in Mass media for the nineties: the South African handbook of mass communication, edited by AS de Beer: Pretoria: Van Schaik, 151-172, 1993.

Moran, A. (Ed.). Film policy: International, national and regional perspectives. London: Routlege, 1996.

Shepperson, A. \& Tomaselli, KG. 2002. Restructuring the industry: South African cinema beyond Apartheid. South African Theatre Journal, 16:63-79, 2002.

Tomaselli, K. The cinema of apartheid: race and class in South African film. New York: Smyrna, 1988.

\section{Reports}

National Film and Video Foundation. Indaba 2001: Distribution, Exhibition and Marketing Report. Johannesburg: NFVF, 2001. 
Nel, W. Profile 2000: Towards a viable South African Film Industry. Johannesburg: PricewaterhouseCoopers, 2000 .

South Africa. National Film and Video Foundation Act No. 73 of 199\%. Pretoria: Government Printer, 1997.

\section{Author Information}

Martin P. BOTHA is Associate Professor of Film and Media Studies at the University of Cape Town. He has published more than 200 articles, reports and papers on South African media, including six books on South African cinema. His most recent book is South African Cinema 1896-2010 (Bristol: Intellect, 2012). 